\title{
COMPARISON OF THE ANTIBACTERIAL ACTIVITY OF COW MILK KEFIR AND GOAT MILK KEFIR AGAINST BACTERIA Bacillus cereus
}

\author{
Dwi Suhartanti ${ }^{1}$, Ryan Septian ${ }^{2}$ \\ ${ }^{1}$ Faculty of Mathematics and Natural Sciences, Universitas Ahmad Dahlan, Yogyakarta \\ ${ }^{2}$ Faculty of Pharmacy, Universitas Ahmad Dahlan, Yogyakarta \\ email: ryanseptian21@gmail.com
}

\begin{abstract}
Background: Kefir is fermented milk and comes from the Caucasus. Kefir is made by inoculating cow milk, goat or sheep with kefir grain. Kefir contains $0.5-1.0 \%$ alcohol and 0.9 to $1.1 \%$ lactic acid. This product is very popular in the Soviet Union, where the consumption of kefir reach $4.5 \mathrm{~kg}$ per capita per year. Kefir made from pasteurized milk and fermented with kefir grain, kefir grain is white seeds from bacteria colony, such as Streptococcus sp., Lactobacilli and some types of yeast/yeast apatogen. As a probiotic drink, kefir contains bacteria of lactic acid and acetic acid bacteria in kefir are giving acidity and produces secondary metabolites that bacteriocins that kill pathogenic bacteria such as Bacillus cereus.

Method: This study used cow milk and goat milk kefir as a starting material, to produce a cow milk kefir and goat milk kefir. Cow milk kefir and goat milk kefir were compared antibacterial activity against Bacillus cereus. Previously each made 3 variations of the concentration of $2 \%$, $4 \%$, and $6 \%$ kefir grains were added cow milk and goat milk. Antibacterial activity tested using Kirby Bauer method so that the observation a clear zone formed on the media was the inhibition activity of the bacterium Bacillus cereus. The results were analyzed by ANOVA, Mann Whitney, and Tukey with a significance of $95 \%$.

Result: The results showed that goat milk kefir has better antibacterial activity against Bacillus cereus compared to cow milk kefir. Goat milk kefir with kefir seeds concentration of $6 \%$ has the best antibacterial activity with inhibition zone diameter of $6 \mathrm{~mm}$.
\end{abstract}

Keywords: kefir, Bacillus cereus, cow milk, goat milk

\section{Introduction}

Antibacterial activity component is a component that can inhibit the growth of bacteria or mold (bacteristatic or fungistatic) or kill bacteria or mold (bactericidal or fungicidal). Several active substances contained in various kinds of plant extracts known to inhibit some pathogenic microbes and vandal active food. Compound can be derived from plant parts such as seeds, fruits, rhizomes, stems, leaves, and tubers. ${ }^{1}$

In addition to antibacterial derived from plant extracts, there are also antibacterial derived from living organisms, for example in the beverage probiotic. But the use of antibiotics derived from plant extracts have a weakness when compared with the use of probiotics for the treatment of bacterial infections of the gastrointestinal tract. This occurs due to the use of plant extracts antibiotics not only kill the bacteria or inhibit bad bacteria but also kill the good bacteria needed by the digestive tract.

According Albaarri and Murti (2003) kefir is a fermented milk products by using lactic acid bacteria such as Lactobacillus lactis, Lactobacillus delbrueckii subsp. bulgaricus, the yeast in the fermentation process produces acids and alcohols. ${ }^{2}$ At the final stage of the process is done in sealed packages for the purpose of carbonate production. Kefir is obtained through a fermentation process using pasteurized milk such as kefir starter grains, ie grains of white or cream from the collection of bacteria, such as Streptococcus sp, Lactobacilli and some types of yeast, yeast pathogenic. ${ }^{3}$ 
The milk is an emulsion of fat in water containing dissolved some compounds. To be fat and water in milk is not easy to separate, so milk protein acts as an emulsifier (emulsifier). The water content in milk is very high, which is about $87.5 \%$, the content of the milk sugar (lactose) of about $5 \%$, about $3.5 \%$ protein, and fat around $3-4 \%$. 's Milk is also a source of calcium, phosphorus, and vitamin $A$ is very good. ${ }^{4}$

Bacillus cereus is a Gram-positive, facultative aerobic, and can form large rodshaped spora. Bacillus cereus adalah soil organisms that often rice contaminatei. Disease that can be caused by the bacteria Bacillus cereus ie vomiting, diarrhea and stomach ache. III due to poisoning bacteria Bacillus cereus food intoxication occurs the entry of enterotoxin produced by Bacillus cereus to human body. Bacillus may represent digestive tract bacteria and very growth fast and easy handling. Based on the above, the author would like to obtain a formulation kefir which has antibacterial activity against. Bacillus cereus well, by comparing which is better between the antibacterial activity of milk kefir and goat milk kefir.

\section{Research Method}

The tools used to make kefir are analytical balance, pan, stove, filter rubber, measuring cup, sealed glass container (all the tools used in the manufacture of Kefir in a sterile state). The instrument used to test lactic acid bacteria colony counts are test tubes, petridishes, propipet, incubators, pipettes volume, bunsen lamp. The instrument used to test the antibacterial activity are micro-pipette, yellow tip, spritus, sterile cotton swab (sterile Invasive Eurotubo, Swab Collection), cotton, and OSE.

The materials used in the manufacture of fresh cow's milk kefir namely, fresh goat milk, kefir grains. The materials used for the calculation of lactic acid bacteria colonies that Kefir starter with a wide range of concentrations, MRSA media, physiological $\mathrm{NaCl}$ solution. Materials used to test the antibacterial activity is Bacillus cereus, Kefir, media nutrient agar, physiological saline solution and alcohol.

\section{Procedure:}

\section{A. Making cow milk kefir and goat milk kefir}

Fresh milk (cow milk/dairy goats) boiling at $85-90^{\circ} \mathrm{C}$ for 30 minutes and then cooled to room temperature, added $2 \%, 4 \%$, and $6 \%$ kefir grains and seeds in stir evenly, incubation at room temperature for 20-24 hours, when it clot filter with a plastic filter to get back buji kefir. And fresh kefir obtained with a concentration of $2 \%, 4 \%$, and $6 \%$.

\section{B. Antibacterial test}

\section{a. Sterilization}

All equipment used such as volumetric flask, erlenmeyer, measuring pipettes, pipette volume, and other glass instruments sterilized in an oven at a temperature of $170^{\circ} \mathrm{C}$ for 2 hours, while the yellow tip, medium and distilled water, $\mathrm{NaCl} 0,9 \%$ sterilized by autoclave at a temperature of $121^{\circ} \mathrm{C}$ for 15 minutes.

\section{b. Antibacterial Activity Test}

\section{1) Preparation of Bacterial Suspension}

Preparation of bacterial suspension was done by taking one colony of bacteria stock bacterium $B$. cereus as many as 1 loop, then put in $1 \mathrm{~mL}$ of $\mathrm{BHI}$ and incubated for $18-24$ hours at $37^{\circ} \mathrm{C}$, after incubation was taken as $100 \mathrm{~mL}$ of $1 \mathrm{~mL} \mathrm{BHI}$ already incubated and put in $1 \mathrm{~mL} \mathrm{BHI}$ back then incubated for 4-8 hours at $37^{\circ} \mathrm{C}$, then diluted with incubation results using $0,9 \% \mathrm{NaCl}$ to a turbidity equal to Mc Farland standard is a concentration of $10^{8} \mathrm{CFU} / \mathrm{mL}$, after turbidity equal to Mc Farland which means that the concentration is $10^{8}$ 
$\mathrm{CFU} / \mathrm{mL}$ and then diluted again with $\mathrm{BHI}$ medium until turbidity DS $10^{6}$ $\mathrm{CFU} / \mathrm{mL}$, so that the concentration of the bacterial suspension $\mathrm{B}$. cereus that used to test antibacterial activity is at a concentration of $10^{6} \mathrm{CFU} / \mathrm{mL}$.

The method used in the antibacterial activity test is a paper disc diffusion method. With the paper disc diffusion method is expected sample can be observed inhibition zone against Bacillus cereus. This method has several advantages that can be used to test samples have turbidity and easy in his observations that measure the diameter of inhibition zone test material to the activity of test bacteria. The first way is performed using a micropipette is taken $100 \mathrm{~mL}$ bacterial suspension that had previously been measured turbidity, then dripped and smeared on the surface of nutrient agar medium to spread it flat on the way back and forth across the surface of the medium until smooth. It should be noted at the time of greasing, motion smear should be careful so that the surface is not damaged media. If the order is damaged then the nutrient media will affect the results obtained are not in accordance with what is expected due to a suspension that has been applied, will seep and spread to the order. Once applied then placed on a paper disc media containing kefir $2 \%, 4 \%, 6 \%$, positive and negative controls dick which has a diameter of $6 \mathrm{~mm}$ on each paper disc media. Each media given by 5 . Then after that, the media were incubated at $37^{\circ} \mathrm{C}$ for 24 hours. The results of incubation can be observed that the clear zone is formed, after which the clear zone diameters were measured using a ruler.

\section{Data analysis}

Data were analyzed by some statistic tests. Preliminary test employed Kolgomorov-Smirnov test to check the normality of the data and Levene test for homogeneity of the data see. If the data were normally distributed and homogeneous tested $(p>0.05)$, then followed by a parametric test includes a paired test, ANOVA followed one path Tukey's t test and Duncan with a level of $95 \%$ to show a significant difference between group pairs. If the Kolmogorov-Smirnov and Levene's test was not obtained and homogenya normal distribution, then followed by a non-parametric test, namely the Wilcoxon test.

\section{Results and Analysis}

The initial amount of kefir starter grains used in the initial study design was at $2 \%$ of the total milk $\mathrm{mL}$ of medium used, then see the result, if it formed the initial amount of kefir starter made the smallest is $2 \%$ (of the amount of milk used medium), but if it has not formed kefir, kefir aking is carried out by the number concentration of $4 \%$ (of the amount of milk used medium).

Comparison between cow milk kefir and goat milk kefir almost entirely the same except the color of the cow milk kefir is slightly more yellow than goat milk kefir because there are carotenoids in cow milk, and for consistency, flavor, aroma, and flavor is similar to cow milk kefir and goat milk kefir.

Table 1. Comparison of the results of research and product kefir commercial kefir

\begin{tabular}{cccc}
\hline Comparison & Kefir products & Kefir milk & Goat milk kefir \\
\hline Taste & Typical acid & Acid & Acid \\
consistency & thick & thick & thick \\
aroma & typical kefir & typical kefir & typical kefir \\
acidity & acid & acid & acid \\
color & white & white & slightly yellow \\
\hline
\end{tabular}


Table 2. Interpretation of Results of Mann Whitney test goat milk kefir

\begin{tabular}{|c|c|c|c|c|c|}
\hline Group & control (+) & $2 \%$ & $4 \%$ & $6 \%$ & Control (-) \\
\hline Control (+) & & $\begin{array}{c}\text { Sig: } 0,105 \\
\text { Was not } \\
\text { significantly } \\
\text { different }\end{array}$ & $\begin{array}{l}\text { Sig: } 0,043 \\
\text { significantly } \\
\text { different }\end{array}$ & $\begin{array}{c}\text { Sig: } 0,197 \\
\text { Was not } \\
\text { significantly } \\
\text { different }\end{array}$ & $\begin{array}{c}\text { Sig: } 0,034 \\
\text { significantly } \\
\text { different }\end{array}$ \\
\hline $2 \%$ & $\begin{array}{c}\text { Sig: } 0,105 \\
\text { Was not } \\
\text { significantly } \\
\text { different }\end{array}$ & & $\begin{array}{c}\text { Sig: } 0,817 \\
\text { Was not } \\
\text { significantly } \\
\text { different }\end{array}$ & $\begin{array}{c}\text { Sig: } 0,246 \\
\text { Was not } \\
\text { significantly } \\
\text { different }\end{array}$ & $\begin{array}{c}\text { Sig: } 0,037 \\
\text { significantly } \\
\text { different }\end{array}$ \\
\hline $4 \%$ & $\begin{array}{l}\text { Sig: 0,043 } \\
\text { significantly } \\
\text { different }\end{array}$ & $\begin{array}{c}\text { Sig: } 0,817 \\
\text { Was not } \\
\text { significantly } \\
\text { different }\end{array}$ & & $\begin{array}{c}\text { Sig: } 0,068 \\
\text { Was not } \\
\text { significantly } \\
\text { different }\end{array}$ & $\begin{array}{c}\text { Sig: 0,034 } \\
\text { significantly } \\
\text { different }\end{array}$ \\
\hline $6 \%$ & $\begin{array}{c}\text { Sig: } 0,197 \\
\text { Was not } \\
\text { significantly } \\
\text { different }\end{array}$ & $\begin{array}{c}\text { Sig: } 0,246 \\
\text { Was not } \\
\text { significantly } \\
\text { different }\end{array}$ & $\begin{array}{c}\text { Sig: } 0,068 \\
\text { Was not } \\
\text { significantly } \\
\text { different }\end{array}$ & & $\begin{array}{c}\text { Sig: 0,034 } \\
\text { significantly } \\
\text { different }\end{array}$ \\
\hline Control (-) & $\begin{array}{c}\text { Sig: } 0,034 \\
\text { significantly } \\
\text { different }\end{array}$ & $\begin{array}{c}\text { Sig: } 0,037 \\
\text { significantly } \\
\text { different }\end{array}$ & $\begin{array}{c}\text { Sig: } 0,034 \\
\text { significantly } \\
\text { different }\end{array}$ & $\begin{array}{c}\text { Sig: } 0,034 \\
\text { significantly } \\
\text { different }\end{array}$ & \\
\hline
\end{tabular}

From the results of Mann Whitney above, it can be seen that the results of inhibition zone diameter of the control group (+) group only differed significantly by $4 \%$, this suggests that in fact Antibiotics used as control (+) has antibacterial activity similar to kefir group against Bacillus cereus. Then inhibition zone diameter between groups $2 \%, 4 \%$, and $6 \%$ showed no significant difference in the relationship, meaning that it is increasing the number of kefir starter used is not too significant effect on the ability of antibacterial against Bacillus cereus bacteria. But it can be concluded that among the treatment groups $2 \%, 4 \%$, and $6 \%, 6 \%$ group has the ability or the inhibition of antibacterials the largest among the three.

Table 3. The results of ANOVA test interpretation cow milk kefir

\begin{tabular}{|c|c|c|c|c|c|}
\hline Group & control + & $2 \%$ & $4 \%$ & $6 \%$ & Control - \\
\hline Control + & & $\begin{array}{l}\text { Sig: } 0,000 \\
\text { significantly } \\
\text { different }\end{array}$ & $\begin{array}{c}\text { Sig: } 0,000 \\
\text { significantly } \\
\text { different }\end{array}$ & $\begin{array}{l}\text { Sig: } 0,000 \\
\text { significantly } \\
\text { different }\end{array}$ & $\begin{array}{c}\text { Sig: } 0,000 \\
\text { significantly } \\
\text { different }\end{array}$ \\
\hline $2 \%$ & $\begin{array}{l}\text { Sig: } 0,000 \\
\text { significantly } \\
\text { different }\end{array}$ & & $\begin{array}{c}\text { Sig: 0,034 } \\
\text { significantly } \\
\text { different }\end{array}$ & $\begin{array}{l}\text { Sig: } 0,000 \\
\text { significantly } \\
\text { different }\end{array}$ & $\begin{array}{c}\text { Sig: 0,283 } \\
\text { Was not } \\
\text { significantly } \\
\text { different }\end{array}$ \\
\hline $4 \%$ & $\begin{array}{l}\text { Sig: } 0,000 \\
\text { significantly } \\
\text { different }\end{array}$ & $\begin{array}{c}\text { Sig: } 0,034 \\
\text { significantly } \\
\text { different }\end{array}$ & & $\begin{array}{l}\text { Sig: } 0,004 \\
\text { significantly } \\
\text { different }\end{array}$ & $\begin{array}{c}\text { Sig: } 0,002 \\
\text { significantly } \\
\text { different }\end{array}$ \\
\hline $6 \%$ & $\begin{array}{l}\text { Sig: } 0,000 \\
\text { significantly } \\
\text { different }\end{array}$ & $\begin{array}{l}\text { Sig: } 0,000 \\
\text { significantly } \\
\text { different }\end{array}$ & $\begin{array}{c}\text { Sig: } 0,004 \\
\text { significantly } \\
\text { different }\end{array}$ & & $\begin{array}{c}\text { Sig: } 0,000 \\
\text { significantly } \\
\text { different }\end{array}$ \\
\hline Control - & $\begin{array}{l}\text { Sig: } 0,000 \\
\text { significantly } \\
\text { different }\end{array}$ & $\begin{array}{c}\text { Sig: } 0,283 \\
\text { Was not } \\
\text { significantly } \\
\text { different }\end{array}$ & $\begin{array}{l}\text { Sig: } 0,002 \\
\text { significantly } \\
\text { different }\end{array}$ & $\begin{array}{l}\text { Sig: } 0,000 \\
\text { significantly } \\
\text { different }\end{array}$ & \\
\hline
\end{tabular}

KESMAS Vol. 8, No. 2, September 2014 : 71 - 76 
From the ANOVA results above, it can be seen that the results of inhibition zone diameter of the control group (+) significantly different from all groups (groups $2 \%, 4 \%$, $6 \%$, and control (-)) this shows that in fact Antibiotics are used as control (+) activity greatest antibacterial against Bacillus cereus bacteria. Then inhibition zone diameter between groups $2 \%, 4 \%$, and $6 \%$ showed a significant difference, meaning that is increasing the number of kefir starter used fairly significant effect on the antibacterial ability of the bacteria Bacillus cereus. It is quite interesting seen between $2 \%$ and control group (-) which has a relationship was not significant, which means $2 \%$ group has no significant difference with the control (-) in inhibiting the growth of bacteria Bacillus cereus. So can be concluded that the treatment group between $2 \%, 4 \%$, and $6 \%$. $6 \%$ group has the ability or the inhibition of antibacterials the largest among the three.

Before the test comparison between cow milk kefir and goat milk kefir, Normality test first. And the results obtained $p$ value is $0.675>0.05$ so that the above data are normally distributed. Then next homogeneity test, significance value obtained is $0.045>0.05$, then the data above is not having the same variant or not homogeneous, because the data were normally distributed, but the data are not homogeneous, then performed the Mann Whitney test to look at differences between groups of data. Mann Whitney test results can be found in the appendix. From the results of Mann Whitney, it can be said that among the group of cow milk kefir and water kefir goat milk no significant difference between the $2 \%$ and $6 \%$ group, but no significant difference in group 4\% Next, Duncan test. Duncan test results can be seen in attachment, order of inhibition zone diameter of the largest to the smallest is kefir $2 \%$ cow milk, cow milk kefir $4 \%$, water kefir $2 \%$ goat milk, goat milk kefir $4 \%$, kefir $6 \%$ cow milk and goat milk kefir last $6 \%$. Then the result interpretation of inhibition zone comparison to cow milk kefir and goat milk kefir exist in the table below:

Table 4. Interpretation of Results Comparison inhibition zone between cow milk kefir and goat milk kefir

\begin{tabular}{ll}
\hline \multicolumn{1}{c}{ Comparison } & \multicolumn{1}{c}{ ANOVA test results } \\
\hline $2 \%$ goat milk kefir and kefir $2 \%$ cow milk & Was not significantly different \\
$4 \%$ goat milk kefir and milk kefir $4 \%$ & significantly different \\
$6 \%$ goat milk kefir and milk kefir $6 \%$ & Was not significantly different \\
\hline
\end{tabular}

From the above results it can be concluded that statistically, there was no significant difference between the ability of antibacterials kefir milk cow and goat milk kefir against the bacteria Bacillus cereus. And if viewed an average of the two groups between cow milk kefir and goat milk kefir, the largest average in general is goat so milk kefir goat milk is more suitable for use as a fermentation medium of making kefir.

\section{Conclusion}

a. Goat milk kefir has better antibacterial activity compared with cow milk kefir against Bacillus cereus.

b. Antibacterial formula with the greatest activity is kefir grains with the addition of $6 \%$ of the amount of milk used.

\section{Acknowledgements}

Dean of Faculty of Mathematics and Natural Sciences, Ahmad Dahlan University Dean of the Faculty of Pharmacy, Ahmad Dahlan University

Rector of Ahmad Dahlan University 


\section{References}

1. Ardiansyah, Daun Beluntas Sebagai Bahan Antibakteri dan Antioksidan, Artikel Iptek Bidang Biologi, Pangan, dan Kesehatan, 2005.

2. Albaarri AN dan Murti TW, Analisa pH, Keasaman dan Kadar Laktosa pada Yakult, Yoghurt, Kefir, Proceeding Simposium Nasional Hasil-hasil Penelitian, Unika Soegijapranata, Semarang 22 Maret 2003, 2003.

3. Usmiati S, Kefir, Susu Fermentasi dengan Rasa Menyegarkan, Warta Penelitian dan Pengembangan Pascapanen Pertanian, vol/no: 29(2), pp. 12-17, 2007.

4. Widodo W, Bioteknologi Fermentasi Susu, Pusat Pengembangan Bioteknologi Universitas Muhammadiyah Malang, Jawa Timur, 2002. 